[Article]

\title{
1-丁基-3-甲基咪唑六氟磷酸盐+水+醇体系的相行为
}

\author{
宁 汇侯民强梅清清杨德重 韩布兴* \\ (中国科学院化学研究所, 中国科学院胶体界面与化学热力学重点实验室, 北京分子科学国家实验室, 北京 100190)
}

\begin{abstract}
摘要: 在 $298.15 \mathrm{~K}$, 常压下研究了 1-丁基-3-甲基咪唑六氟磷酸盐([bmim] $\left[\mathrm{PF}_{6}\right]$ )+水+甲醇、[bmim] $\left[\mathrm{PF}_{6}\right]+$ 水 +乙 醇、 $[\mathrm{bmim}]\left[\mathrm{PF}_{6}\right]+$ 水+2-丙醇、 $\left[\mathrm{bmmim}_{[}\left[\mathrm{PF}_{6}\right]+\right.$ 水+1-丙醇三元体系的相行为. 结果表明, 对于含甲醇、乙醇和 2-丙醇 的体系, 醇在水+醇溶液中摩尔分数分别为 $0.55-1.00 、 0.40-0.75$ 和 $0.35-0.50$ 时, 醇的水溶液与 $\left[\mathrm{bmim}^{-}\left[\mathrm{PF}_{6}\right]\right.$ 可以互溶. 而水 +1 -丙醇体系没有此类现象. 这说明, 这类三元系的相行为不但取决于醇分子的大小, 而且取决 于其结构.
\end{abstract}

关键词: 离子液体; 水; 醇; 相行为; 共溶剂效应 中图分类号: 0642

\section{Phase Behaviors of 1-Butyl-3-methylimidazolium Hexafluorophosphate+Water+Alcohol Systems}

\author{
NING Hui HOU Min-Qiang MEl Qing-Qing YANG De-Zhong HAN Bu-Xing* \\ (Beijing National Laboratory for Molecular Sciences, CAS Key Laboratory of Colloid, Interface and Chemical Thermodynamics, \\ Institute of Chemistry, Chinese Academy of Sciences, Beijing 100190, P. R. China)
}

\begin{abstract}
The phase behaviors of 1-butyl-3-methylimidazolium hexafluorophosphate ([bmim] $\left.\left[\mathrm{PF}_{6}\right]\right)+$ water+methanol, $[\mathrm{bmim}]\left[\mathrm{PF}_{6}\right]+$ water+ethanol, $[\mathrm{bmim}]\left[\mathrm{PF}_{6}\right]+$ water+2-propanol, and $[\mathrm{bmim}]\left[\mathrm{PF}_{6}\right]+$ water+1propanol ternary systems were determined at $298.15 \mathrm{~K}$ and ambient pressure. It was demonstrated that when the mole fractions of the alcohols in the water+alcohol solutions were $0.55-1.00,0.40-0.75$, and $0.35-0.50$ for methanol, ethanol, and 2-propanol, respectively, the [bmim] $\left[\mathrm{PF}_{6}\right]$ was totally dissolved in the aqueous alcohol solutions due to a strong co-solvent effect. However, water+1-propanol did not exhibit this kind of behavior. Both the size and structure of the alcohols significantly affected the phase behaviors of the ternary systems.
\end{abstract}

Key Words: Ionic liquid; Water; Alcohol; Phase behavior; Co-solvent effect

\section{Introduction}

Room-temperature ionic liquids (ILs) are organic salts with low melting points (usually below $100{ }^{\circ} \mathrm{C}$ ), which are composed of cations and anions. ILs have some unique properties, such as negligible vapor pressure at mild conditions, wide liquid temperature range, nonflammability, strong solvent power for both organic and inorganic substances. ${ }^{1}$ ILs have wide potential applications in different fields, including chemical reactions, ${ }^{2,3}$ material science, ${ }^{4}$ separation, etc. ${ }^{5,6}$

In recent years, study of physiochemical properties, ${ }^{6-20}$ in- cluding the phase behaviors ${ }^{6-12}$ and other thermodynamic properties $^{13-15}$ has attracted much attention due to the importance from both scientific and practical viewpoints. The phase behaviors of the systems containing both ILs and alcohols and/or water have also been studied. For example, the phase behaviors of $\mathrm{IL}+$ alcohol $^{21,22}$ and IL + water $^{23}$ binary systems have been studied by different authors. The phase behaviors of some IL+water + alcohol ternary systems and the co-solvent effects in the systems have also been investigated. ${ }^{24-27}$ It was shown that [bmim] $\left[\mathrm{PF}_{6}\right]$, a hydrophobic IL, could be totally miscible with

Received: December 11, 2012; Revised: January 28, 2013; Published on Web: January 31, 2013.

"Corresponding author. Email: hanbx@iccas.ac.cn; Tel: +86-10-62562821.

The project was supported by the National Natural Science Foundation of China (20903109, 21073207).

国家自然科学基金(20903109, 21073207)资助项目

(C) Editorial office of Acta Physico-Chimica Sinica 
aqueous ethanol in certain mole fraction range of ethanol, ${ }^{24,25}$ whereas it was only partially miscible with either pure water or absolute ethanol.

Study of the dependence of phase behaviors of multi-component IL systems on the structures of the components is still a very interesting topic, although some systems have been studied. Water is a typical green solvent. Alcohols are commonly used solvents and reactants. [bmim] $\left[\mathrm{PF}_{6}\right]$ is one of the typical ILs. Freire et al. ${ }^{28}$ studied hydrolysis properties of [bmim] [ $\left.\mathrm{PF}_{6}\right]$, and the result indicated that the hydrolysis of the IL at moderate temperatures was negligible even for long time periods. Investigation of the effect of size and structure of alcohols on the phase behavior of IL+water+alcohol systems is of interest both academically and practically. In this work, we studied the phase behaviors of $[\mathrm{bmim}]\left[\mathrm{PF}_{6}\right]+$ water + methanol, $[\mathrm{bmim}]\left[\mathrm{PF}_{6}\right]+$ water+ethanol, $[\mathrm{bmim}]\left[\mathrm{PF}_{6}\right]+$ water+2-propanol, and $[\mathrm{bmim}]\left[\mathrm{PF}_{6}\right]+$ water+1-propanol systems, and the effect of the alcohol structure on the phase behaviors was investigated. Our literature survey indicated that except for $[\mathrm{bmim}]\left[\mathrm{PF}_{6}\right]+$ water+ethanol system, the phase behaviors of the other three systems have not been reported. The results indicate that the phase behaviors of the $[\mathrm{bmim}]\left[\mathrm{PF}_{6}\right]+$ water + alcohol systems depend strongly on both the size and the structure of alkyl chains of the alcohols.

\section{Experimental}

\subsection{Materials}

The IL $[$ bmim $]\left[\mathrm{PF}_{6}\right]$ (purity, $\geq 99 \%$ ) were provided by Lanzhou Greenchem ILS, Chinese Academy of Science, China. Before the experiment, the IL was dried under vacuum at $70^{\circ} \mathrm{C}$ until the mass was not changed with drying time, and the content of water in the IL was less than $0.03 \%$ (mass fraction) by Karl Fischer titration (751 GPD Titrino, Metrohm, Switzerland). The anhydrous methanol ( $>99.7 \%)$, ethanol $(>99.7 \%)$, 1-propanol (>99.7\%), and 2-propanol (>99.7\%), were purchased from Sinopharm Chemical Reagent Co., Ltd. Triply distilled water was used in all the experiments.

\subsection{Apparatus and procedures}

The phase behaviors of the systems were determined by cloud-point titration method, which was similar to those used by other authors. ${ }^{22,25,26}$ The apparatus were mainly consisted of a constant temperature water bath, a glass bottle (ca $50 \mathrm{~mL}$ ), syringes of different volumes, and a magnetic stirrer. The constant temperature water bath was maintained at $(298.15 \pm 0.05)$ $\mathrm{K}$ by an YKKY A2 temperature controller (Beijing Changliu Scientific Instruments Co., Ltd.). An AR224CN balance (Ohas Instruments Co., Ltd., Shanghai, China) with an uncertainty of $0.0001 \mathrm{~g}$ was used to determine the masses of the components.

To determine the phase behavior of the ternary system, a water-IL sample (ca $10 \mathrm{~mL}$ ) with known composition was titrated with ethanol, or an ethanol-IL sample (ca $10 \mathrm{~mL}$ ) with known composition was titrated with water in a glass bottle. A syringe of suitable size was used to add water or alcohol to the glass bottle. During the titration, the mixture was stirred until the phase transition from turbidity to clarity or from clarity to tur- bidity was observed. The mass of the added alcohol or water was determined by weighing the syringe before and after the titration. Reaching equilibrium was crucial for the experiments. To ensure that the equilibrium was reached after a titration, the phase behavior of the system was observed until it was independent of time. The equilibrium time was at least $24 \mathrm{~h}$.

To determine the phase behavior of a $[\mathrm{bmim}]\left[\mathrm{PF}_{6}\right]+$ water or [bmim $]\left[\mathrm{PF}_{6}\right]+$ alcohol binary system, suitable amount of mixture was sealed in the glass bottle that was immersed in the constant temperature water bath. The bottle was shaken for about $10 \mathrm{~min}$, and then equilibrated at static condition. After phase equilibrium had been reached, the IL-rich phase and water/alcohol-rich phase were sampled using syringes, and the samples were placed in glass tubes separately. The samples were dried at $70{ }^{\circ} \mathrm{C}$ under vacuum to remove the water or alcohol completely, which was known by the fact that the mass of the samples was independent of drying time. The masses of the IL and water or alcohol in the samples were easily known from the masses changes of the glass tubes. To confirm that the analytical method was reliable, we carried out control experiments using $[\mathrm{bmim}]\left[\mathrm{PF}_{6}\right]+$ water and $[\mathrm{bmim}]\left[\mathrm{PF}_{6}\right]+$ alcohol binary mixtures of known composition by the same procedures. The results indicated that the after drying, the content of water or an alcohol in the IL was less $0.03 \%$. In the experiments, equilibrium was confirmed by the fact that the data obtained at different times were the same.

\section{Results and discussion}

The cloud point data of $[\mathrm{bmim}]\left[\mathrm{PF}_{6}\right]+$ water + methanol, [bmim $]\left[\mathrm{PF}_{6}\right]+$ water+ethanol, $[$ bmim $]\left[\mathrm{PF}_{6}\right]+$ water+2-propanol, and $[$ bmim $]\left[\mathrm{PF}_{6}\right]+$ water+1-propanol ternary systems were determined at $298.15 \mathrm{~K}$ and ambient pressure. The miscibility of the sub-binary systems was also determined. All the data are presented in Table 1. The ternary phase diagrams are illustrated in Figs.1-4. It was estimated that the mole fractions in the table can be accurate to \pm 0.002 .

\subsection{Phase equilibria of [bmim] $\left[\mathrm{PF}_{6}\right]+$ alcohol (or water) binary systems}

The IL and methanol were miscible in the entire composition range. The data in Table 1 indicate that the solubilities of water, ethanol, 2-propanol, and 1-propanol in [bmim] $\left[\mathrm{PF}_{6}\right]$ were $25.8 \%$ (molar fraction), $51.7 \%, 32.8 \%$, and $27.3 \%$, respectively. The solubilities of the IL in water, ethanol, 2-propanol, and 1-propanol were $0.14 \%, 0.67 \%, 1.1 \%$, and $0.13 \%$, respectively. The solubility data of the binary systems agree well with the data reported in the literature. ${ }^{21,22}$ The solubility of the alcohols (or water) in [bmim] $\left[\mathrm{PF}_{6}\right]$ follows the order of methanol $>$ ethanol $>2$-propanol $>1$-propanol $>$ water, and the order of the solubility of the IL in alcohols (or water) is methanol> 2-propanol>ethanol $>$ water $\approx 1$-propanol. The mole fraction and mass fraction have the same order.

\subsection{Phase equilibria of $[\mathrm{bmim}]\left[\mathrm{PF}_{6}\right]+$ water+alcohol ternary systems}


Table 1 Cloud point data (in mole fraction $(x)$ ) of [bmim] [PF $]$ (1)+water (2)+alcohol (3) systems at $298.15 \mathrm{~K}$ and ambient pressure

\begin{tabular}{|c|c|c|c|c|c|c|c|c|c|c|c|}
\hline \multicolumn{3}{|c|}{ Methanol } & \multicolumn{3}{|c|}{ Ethanol } & \multicolumn{3}{|c|}{ 2-Propanol } & \multicolumn{3}{|c|}{ 1-Propanol } \\
\hline$x_{1}$ & $x_{2}$ & $x_{3}$ & $x_{1}$ & $x_{2}$ & $x_{3}$ & $x_{1}$ & $x_{2}$ & $x_{3}$ & $x_{1}$ & $x_{2}$ & $x_{3}$ \\
\hline 0.001 & 0.999 & 0 & 0.007 & 0 & 0.993 & 0.011 & 0 & 0.989 & 0.001 & 0 & 0.999 \\
\hline 0.742 & 0.258 & 0 & 0.484 & 0 & 0.517 & 0.672 & 0 & 0.328 & 0.728 & 0 & 0.273 \\
\hline 0.030 & 0.555 & 0.415 & 0.034 & 0.650 & 0.315 & 0.034 & 0.715 & 0.252 & 0.035 & 0.663 & 0.302 \\
\hline 0.056 & 0.497 & 0.447 & 0.066 & 0.594 & 0.340 & 0.071 & 0.639 & 0.290 & 0.062 & 0.557 & 0.381 \\
\hline 0.109 & 0.433 & 0.459 & 0.131 & 0.524 & 0.345 & 0.141 & 0.567 & 0.292 & 0.047 & 0.523 & 0.430 \\
\hline 0.161 & 0.397 & 0.443 & 0.197 & 0.474 & 0.329 & 0.212 & 0.512 & 0.276 & 0.210 & 0.496 & 0.294 \\
\hline 0.309 & 0.335 & 0.356 & 0.384 & 0.378 & 0.238 & 0.345 & 0.428 & 0.227 & 0.298 & 0.457 & 0.246 \\
\hline 0.519 & 0.286 & 0.195 & 0.562 & 0.307 & 0.131 & 0.057 & 0.427 & 0.516 & 0.029 & 0.425 & 0.547 \\
\hline- & - & - & 0.125 & 0.216 & 0.660 & 0.115 & 0.424 & 0.461 & 0.234 & 0.417 & 0.350 \\
\hline- & - & - & 0.062 & 0.213 & 0.726 & 0.184 & 0.394 & 0.422 & 0.284 & 0.373 & 0.343 \\
\hline- & - & - & 0.199 & 0.197 & 0.605 & 0.031 & 0.378 & 0.591 & 0.454 & 0.367 & 0.179 \\
\hline- & - & - & 0.033 & 0.176 & 0.791 & 0.468 & 0.365 & 0.167 & 0.328 & 0.345 & 0.327 \\
\hline- & - & - & 0.357 & 0.105 & 0.538 & 0.267 & 0.331 & 0.402 & 0.597 & 0.308 & 0.095 \\
\hline- & - & - & 0.001 & 0.999 & 0 & 0.583 & 0.320 & 0.097 & 0.428 & 0.241 & 0.331 \\
\hline- & - & - & 0.742 & 0.258 & 0 & 0.380 & 0.251 & 0.370 & 0.552 & 0.142 & 0.306 \\
\hline- & - & - & - & - & - & 0.522 & 0.129 & 0.348 & 0.001 & 0.999 & 0 \\
\hline- & - & - & - & - & - & 0.001 & 0.999 & 0 & 0.742 & 0.258 & 0 \\
\hline- & - & - & - & - & - & 0.742 & 0.258 & 0 & - & - & - \\
\hline
\end{tabular}

For the $[\mathrm{bmim}]\left[\mathrm{PF}_{6}\right]+$ water+methanol system, only one biphase region exists at the experimental temperature (Fig.1) because methanol is miscible with both the IL and water in the whole composition range, and the IL and water are partially miscible.

The $[\mathrm{bmim}]\left[\mathrm{PF}_{6}\right]+$ water+ethanol system has two biphase regions (Fig.2), which is consistent with the results reported by other authors, ${ }^{24-27}$ which confirmed reliability of the apparatus and experimental procedures. Similarly, $[\mathrm{bmim}]\left[\mathrm{PF}_{6}\right]+$ water + 2-propanol system also has two biphase regions, as can be known from Fig.3. As shown in Fig.2 and Fig.3, although [bmim $]\left[\mathrm{PF}_{6}\right]$ is only partially miscible with water, ethanol, and 2-propanol, it can be totally miscible with the water-alcohol mixtures when the mole fraction of the alcohols is $0.40-0.75$ for ethanol and $0.35-0.50$ for 2-propanol, respectively. In addition, the figures also show that the monophase region becomes smaller with increasing the carbon number of the alcohols.

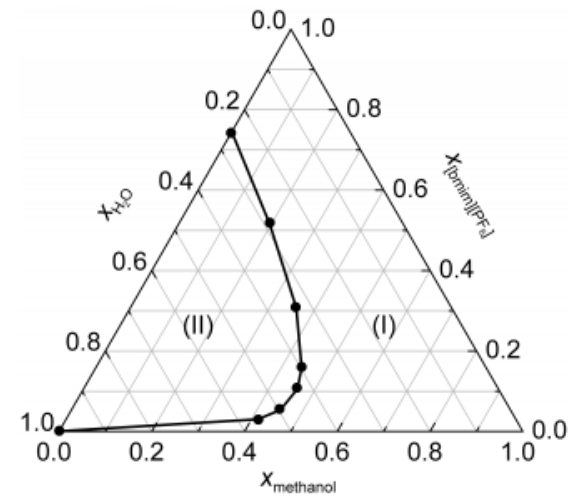

Fig.1 Ternary phase diagram of $[\mathrm{bmim}]\left[\mathrm{PF}_{6}\right]+$ water+methanol system at $298.15 \mathrm{~K}$ and ambient pressure

(I) and (II) stand for monophase region and biphase region, respectively.
Fig.4 demonstrates that the two biphasic regions meet together to form a large biphasic region for the $[\mathrm{bmim}]\left[\mathrm{PF}_{6}\right]+$ wa-

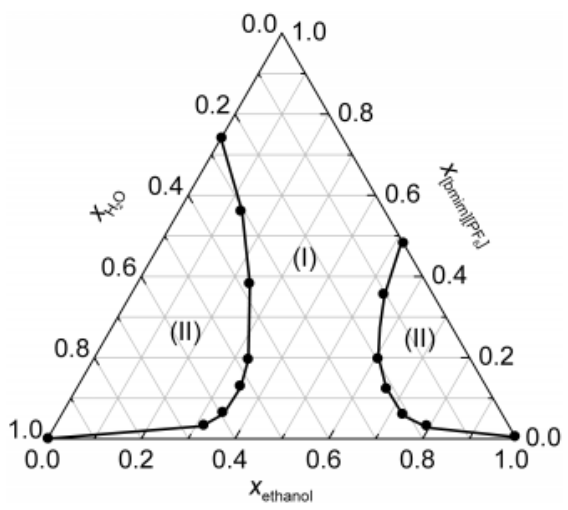

Fig.2 Ternary phase diagram of $[\mathrm{bmim}]\left[\mathrm{PF}_{6}\right]+$ water +ethanol system at $298.15 \mathrm{~K}$ and ambient pressure

(I) and (II) stand for monophase region and biphase region, respectively.

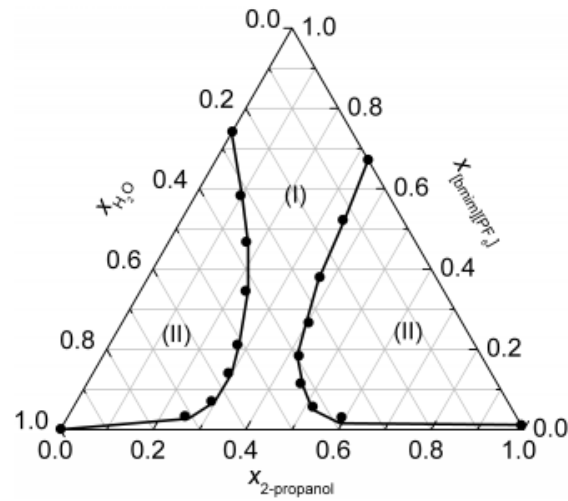

Fig.3 Ternary phase diagram of $[\mathrm{bmim}]\left[\mathrm{PF}_{6}\right]+$ water+2-propanol system at 298.15 $\mathrm{K}$ and ambient pressure

(I) and (II) stand for monophase region and biphase region, respectively. 


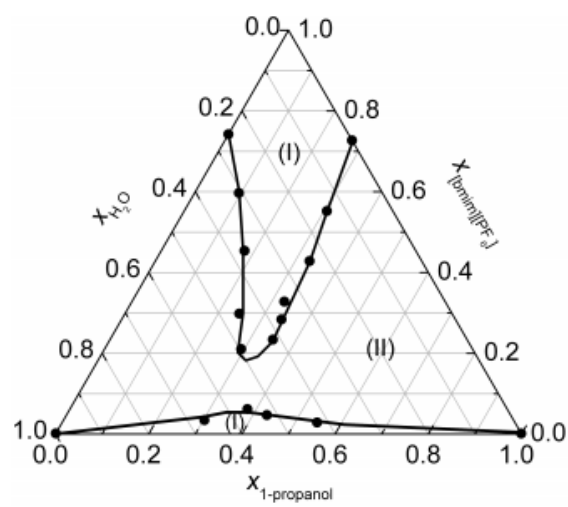

Fig.4 Ternary diagram of $[\mathrm{bmim}]\left[\mathrm{PF}_{6}\right]+$ water+1-propanol system at $298.15 \mathrm{~K}$ and ambient pressure

(I) and (II) stand for monophase region and biphase region, respectively.

ter+1-propanol system, leaving two narrow monophase regions at the bottom and top regions. It can be concluded from Fig. 3 and Fig. 4 that the co-solvent effect of the alcohols depends strongly on the structures of the alcohols. The water-alcohol co-solvent effect of 2-propanol is much larger than that of 1-propanol.

It is known that the phase behaviors of mixtures depend on many factors, such as the size and structures of the components and intermolecular interactions in the systems. Detailed explanation for the effects of the alcohols on the phase behaviors of the $[\mathrm{bmim}]\left[\mathrm{PF}_{6}\right]+$ water + alcohol systems is very interesting, but is very difficult. Co-solvent effect exists in various kinds of multi-component mixtures, including IL-based systems. Some authors ${ }^{27,29}$ have suggested that the water molecules prefer to interact with the anions of ILs by H-bond and an alcohol also has the ability to form H-bond with the anions of ILs. ${ }^{21,30,31}$ Rogers and coworkers ${ }^{25}$ believed that ethanol and water may form special structures and free-volume cavities, or void space within the IL matrix which may allow ethanol and water to be dissolved together, whilst maintaining the bulk ethanol/water H-bonding structure with only weak interactions between the alkyl-groups of the IL and the hydrophobic ethyl-substituents of the ethanol chains. Najdanovic-Visak and coworkers ${ }^{26,27}$ gave a more direct evidence to confirm that the water cosolvent effect does play an important role in liquid-liquid equilibrium of IL-alcohol systems. Brennecke and coworkers ${ }^{21}$ indicated that the solubility of alcohols in the IL-rich phase is higher for branched alcohols than it is for linear alcohols, which may be explained by the H-bond interaction between alcohols and ILs that is infected considerably by the structure of alcohols with the same carbon number. Accordingly, the co-solvent effect can be influenced not only by the length of the chain but also the structure of the alcohols.

For the ternary systems studied in this work, the co-solvent effect of the alcohols affects the phase behaviors significantly. The smaller alcohols are more miscible with both the IL and water, and their co-solvent effect is larger. Similar with the results reported, ${ }^{21}$ the branched 2-propanol has a stronger interac- tion with water and $[\mathrm{bmim}]\left[\mathrm{PF}_{6}\right]$ than 1-propanol. Therefore, the co-solvent effect of 2-propanol is stronger than 1-propanol, which is the main reason for the difference between the phase behaviors of $[\mathrm{bmim}]\left[\mathrm{PF}_{6}\right]+$ water+2-propanol and $[\mathrm{bmim}]\left[\mathrm{PF}_{6}\right]+$ water +1 -propanol systems, as shown in Fig.3 and Fig.4.

\section{Conclusions}

The ternary phase behavior of $[\mathrm{bmim}]\left[\mathrm{PF}_{6}\right]+$ water+alcohol systems are studied at $298.15 \mathrm{~K}$ and ambient pressure. [bmim] $\left[\mathrm{PF}_{6}\right]+$ water+methanol has a monophase region and a biphase region. Both $[\mathrm{bmim}]\left[\mathrm{PF}_{6}\right]+$ water + ethanol and $[\mathrm{bmim}]\left[\mathrm{PF}_{6}\right]+$ water + 2-propanol have a monophase region and two biphase regions, and the area of the monophase in the former is larger. However, when the 2-propanol is substituted by 1-propanol, the [bmim $]\left[\mathrm{PF}_{6}\right]+$ water +1 -propanol phase diagram shows two monophase regions and two biphase regions. Both the size and the structure of alkyl chains of the alcohols influence the phase behaviors $[\mathrm{bmim}]\left[\mathrm{PF}_{6}\right]+$ water+alcohol systems significantly.

\section{References}

(1) Freemantle, M.; Welton, T.; Rogers, R. D. An Introduction to Ionic Liquids; RSC Publishing: Cambridge, 2009.

(2) Zhu, Y. H.; Zeng, H. Y.; Li, S. S.; Lu, Z. X.; Ma, C. A. Acta Phys. -Chim. Sin. 2012, 28, 421. [朱英红, 曾红燕, 李姗姗, 陆在祥, 马淳安. 物理化学学报, 2012, 28, 421.] doi: 10.3866/ PKU.WHXB201112122

(3) Gong, Y. Y.; Liu, M.; Jia, S. Y.; Feng, J. P.; Song, C. S.; Guo, X. W. Acta Phys. -Chim. Sin. 2012, 28, 686. [公艳艳, 刘 民, 贾松岩, 冯建萍, 宋春山, 郭新闻. 物理化学学报, 2012, 28 , 686.] doi: 10.3866/PKU.WHXB201112292

(4) Zhao, Y. J.; Zhang, J. L.; Han, B. X.; Song, J. L.; Li, J. S.; Wang, Q. Angew. Chem. Int. Edit. 2011, 50, 636. doi: 10.1002/ anie.v50.3

(5) Chen, Y.; Han, J.; Wang, T.; Mu, T. C. Energy Fuels 2011, 25, 5810. doi: 10.1021/ef201519g

(6) Jin, M.; Hou, Y. C.; Wu, W. Z.; Ren, S. H.; Tian, S. D.; Xiao, L.; Lei, Z. G. J. Phys. Chem. B 2011, 115, 6585. doi: 10.1021/ jp1124074

(7) Zhao, X. Y.; Cao, Y. R.; Cao, G. R.; Xiao, R. J. Acta Phys. -Chim. Sin. 2012, 28, 1411. [赵学艳, 曹宇容, 曹桂荣, 肖瑞杰. 物理化学学报, 2012, 28, 1411.] doi: 10.3866/PKU. WHXB201203262

(8) Xu, X. C.; Peng, C. J.; Liu, H. L.; Hu, Y. Ind. Eng. Chem. Res. 2009, 48, 11189. doi: 10.1021/ie9011722

(9) Chen, Y. H.; Zhang, S. J. J. Chem. Eng. Data 2009, 55, 278.

(10) Wu, C. Z.; Wang, J. J.; Pei, Y. C.; Wang, H. Y.; Li, Z. Y. J. Chem. Eng. Data 2010, 55, 5004. doi: 10.1021/je100604m

(11) Li, X. M.; Shen, C.; Li, C. X. J. Chem. Thermodyn. 2012, 53, 167. doi: 10.1016/j.jct.2012.05.001

(12) Zhang, J. L.; Han, B. X.; Li, J. S.; Zhao, Y. J.; Yang, G. Y. Angew. Chem. Int. Edit. 2011, 50, 9911. doi: 10.1002/anie. v50.42 
(13) Liu, Z. M.; Wu, W. Z.; Han, B. X.; Dong, Z. X.; Zhao, G. Y.; Wang, J. Q.; Jiang, T.; Yang, G. Y. Chem. Eur. J. 2003, 9, 3897.

(14) Zhang, Q. G.; Wei, Y.; Sun, S. S.; Wang, C.; Yang, M.; Liu, Q. S.; Gao, Y. A. J. Chem. Eng. Data 2012, 57, 2185. doi: 10.1021/ je300153f

(15) Fang, D. W.; Tong, J.; Guan, W.; Yang, J. Z. Scientia Sinica Chimica 2010, 40, 1339. [房大维, 佟 静, 关 伟, 杨家振. 中国科学: 化学, 2010, 40, 1339.]

(16) Liu, Q. S.; Yan, P. F.; Yang, M.; Tan, Z. C.; Li, C. P.; Welz-Biermann, U. Acta Phys. -Chim. Sin. 2011, 27, 2762. [刘青山, 颜佩芳, 杨 沝, 谭志诚, 李长平, Welz-Biermann Urs. 物理化学学报, 2011, 27, 2762.] doi: 10.3866/PKU. WHXB20112762

(17) Ning, H.; Hou, M. Q.; Mei, Q. Q.; Liu, Y. H.; Yang, D. Z.; Han, B. X. Sci. China Chem. 2012, 55, 1509. [宁＼cjkstart汇，侯民强， 梅清清, 刘元会, 杨德重, 韩布兴. 中国科学: 化学, 2012, 55, 1509.] doi: $10.1007 / \mathrm{s} 11426-012-4655-1$

(18) Fang, D. W.; Tong, J.; Guan, W.; Wang, H.; Yang, J. Z. J. Phys. Chem. B 2010, 114, 13808. doi: 10.1021/jp107452q

(19) Zhang, L. Q.; Li, H. R. Acta Phys. -Chim. Sin. 2010, 26, 2877. [张力群, 李浩然. 物理化学学报, 2010, 26, 2877.] doi: 10.3866/ PKU.WHXB20101123

(20) Zhang, Q. G.; Wang, N. N.; Wang, S. L.; Yu, Z. W. J. Phys. Chem. B 2011, 115, 11127. doi: 10.1021/jp204305g

(21) Crosthwaite, J. M.; Aki, S.; Maginn, E. J.; Brennecke, J. F. J. Phys. Chem. B 2004, 108, 5113. doi: 10.1021/jp037774x

(22) Sahandzhieva, K.; Tuma, D.; Breyer, S.; Kamps, A. P. S.;
Maurer, G. J. Chem. Eng. Data 2006, 51, 1516. doi: 10.1021/ je050474j

(23) Freire, M. G.; Santos, L. M. N. B. F.; Fernandes, A. M.; Coutinho, J. A. P.; Marrucho, I. M. Fluid Phase Equilib. 2007, 261, 449. doi: 10.1016/j.fluid.2007.07.033

(24) Swatloski, R. P.; Visser, A. E.; Reichert, W. M.; Broker, G. A.; Farina, L. M.; Holbrey, J. D.; Rogers, R. D. Chem. Commun. 2001, 2070.

(25) Swatloski, R. P.; Visser, A. E.; Reichert, W. M.; Broker, G. A.; Farina, L. M.; Holbrey, J. D.; Rogers, R. D. Green Chem. 2002 , 4, 81. doi: 10.1039/b108905f

(26) Najdanovic-Visak, V.; Esperanca, J.; Rebelo, L. P. N.; da Ponte, M. N.; Guedes, H. J. R.; Seddon, K. R.; de Sousa, H. C.; Szydlowski, J. J. Phys. Chem. B 2003, 107, 12797. doi: 10.1021/ jp034576x

(27) Najdanovic-Visak, V.; Esperanca, J.; Rebelo, L. P. N.; da Ponte, M. N.; Guedes, H. J. R.; Seddon, K. R.; Szydlowski, J. Phys. Chem. Chem. Phys. 2002, 4, 1701. doi: 10.1039/b201723g

(28) Freire, M. G.; Neves, C. M. S. S.; Marrucho, I. M.; Coutinho, J. A. P.; Fernandes, A. M. J. Phys. Chem. A 2010, 114, 3744. doi: $10.1021 /$ jp903292n

(29) Cammarata, L.; Kazarian, S. G.; Salter, P. A.; Welton, T. Phys. Chem. Chem. Phys. 2001, 3, 5192. doi: 10.1039/b106900d

(30) Zhu, X. Y.; Sun, H.; Zhang, D. J.; Liu, C. B. J. Mol. Model. 2011, 17, 1997. doi: 10.1007/s00894-010-0879-1

(31) Hanke, C. G.; Atamas, N. A.; Lynden-Bell, R. M. Green Chem. 2002, 4, 107. doi: 10.1039/b109179b 